\title{
Efek pemediasi modal intelektual pada ketidakpastian lingkungan, strategi inovasi dan kinerja organisasi
}

\author{
Fitri Romadhon ${ }^{1}$, Erlina Diamastuti ${ }^{1}$ \\ ${ }^{1}$ Universitas Internasional Semen Indonesia, Jl. Veteran Kompleks PT Semen Indonesia, Gresik, Indonesia
}

\author{
Diterima: 3 Februari 2020 \\ Direvisi: 8 Mei 2020 \\ Disetujui: 16 Mei 2020
}

Koresponding:

Fitri Romadhon

fitri.romadhon@uisi.ac.id

DOI:

http://dx.doi.org/10.17977/

um004v7i22020p119

\section{Abstract}

This study aims to examine the effect of environmental uncertainty on innovation strategies and organizational performance and when combined with intellectual capital as variable that mediate innovation strategies and organizational performance. The research approach used is a quantitative approach through a survey method. The research was carried out by disseminating questionnaires to 55 respondents. Data analysis technique uses partial least square technique which is preceded by testing the instrument, inner and outer models. The results show that all hypotheses were supported. Environmental uncertainty can determine innovation strategies establishment and organizational performance. Meanwhile, the innovation strategy developed by the company can affect organizational performance. In addition, intellectual capital is proven to mediate innovation strategies and organizational performance, thus it can be inferred that innovation strategies become a fruitful factor in improving performance if supported by intellectual capital. This study is inseparable from a number of limitations, such as not involving other variables that can determine organizational performance, the low participation of respondents, so further research is expected to expand the research sample and consider other determinants, for instance management accounting systems and management control systems.

Keywords: Environmental Uncertainty; Innovation Strategy; Intellectual Capital; Organizational Performance

\begin{abstract}
Abstrak
Penelitian ini bertujuan untuk menguji pengaruh ketidakpastian lingkungan terhadap strategi inovasi dan kinerja organisasi dan ketika dikombinasikan dengan modal intelektual sebagai variabel yang diperkirakan dapat memediasi strategi inovasi dan kinerja organisasi. Pendekatan penelitian yang digunakan adalah pendekatan kuantitatif dengan metode survei. Penelitian dilaksanakan dengan menyebarkan kuesioner kepada 55 responden. Teknik analisis data menggunakan teknik partial least square yang didahului dengan pengujian instrumen penelitian inner dan outer model. Hasil penelitian menunjukkan bahwa seluruh hipotesis diterima. Ketidakpastian lingkungan dapat menentukan penentuan strategi inovasi dan kinerja organisasi sedangkan strategi inovasi yang dikembangkan oleh perusahaan dapat memengaruhi kinerja organisasi. Disamping itu, modal intelektual terbukti dapat memediasi strategi inovasi dan kinerja organisasi sehingga dapat disimpulkan bahwa strategi inovasi menjadi faktor yang sangat penting dalam meningkatkan kinerja apabila didukung dengan modal intelektual. Keterbatasan penelitian terletak pada variabel lain yang belum dilibatkan dapat menentukan kinerja organisasi serta rendahnya partisipasi para responden, sehingga penelitian selanjutnya diharapkan dapat memperluas sampel penelitian dan mempertimbangkan faktor penentu lain seperti sistem akuntansi manajemen dan sistem pengendalian manajemen.
\end{abstract}

Kata kunci: Ketidakpastian Lingkungan; Strategi Inovasi; Modal Intelektual; Kinerja Organisasi

\section{PENDAHULUAN}

Ketidakpastian lingkungan menjadikan perusahaan perlu mengembangkan strategi untuk menghadapi persaingan pasar yang sangat ketat dari segi kekuatan maupun volume persaingan yang saat ini sedang tumbuh (Realbusiness co.uk, 2016). Strategi yang dipersiapkan juga perlu mempertimbangkan bagaimana kondisi ketidakpastian yang sedang dihadapi. Contoh ketidakpastian kebijakan yang dimaksud adalah kebijakan mengenai pajak dan isu tentang peraturan yang sering berubah sehingga menjadikan para manajemen puncak semakin bingung atas ketidakpastian tersebut (Colvin, 2012). 
Persaingan dan ketidakpastian lingkungan tidak hanya membutuhkan persiapan strategi tetapi juga bagaimana cara perusahaan untuk dapat memperoleh keunggulan kompetitif seperti dengan cara berinovasi. Beberapa studi terdahulu menunjukkan bahwa inovasi lebih sering dikaitkan dengan faktor internal termasuk manajemen puncak, sumber daya manusia, kemampuan teknologi dan budaya organisasi (Bhattacharjee et al., 2015; Del Canto \& González, 1999; Subramanian \& Nilakanta, 1996). Inovasi juga dapat dipengaruhi oleh faktor eksternal seperti permintaan pasar, tindakan pesaing serta peraturan dari pemerintah (Caruana et al., 2002; Tripsas, 2008; Yalabik \& Fairchild, 2011). Kedua faktor penentu strategi inovasi yang berbeda menunjukkan bahwa strategi dapat disesuaikan dengan kondisi dimana perusahaan berada dan beroperasi.

Penyusunan strategi inovasi tentu membutuhkan dukungan sumber daya internal agar dapat memberikan dampak positif bagi perusahaan. Apabila mengacu pada resource-based theory, pencapaian kinerja seperti yang diharapkan sangat ditentukan oleh faktor-faktor internal dan karakteristik organisasi (Barney, 1991). Salah satu faktor internal tersebut adalah modal intelektual. Modal intelektual diakui sebagai aset tidak berwujud yang dapat digunakan untuk meningkatan kesuksesan dan mendorong organisasi untuk memperoleh manfaat melalui inovasi, kreativitas dan penciptaan nilai (Bontis, Keow, \& Richardson, 2000; Chen Goh, 2005; Pew Tan, Plowman \& Hancock, 2007).

Topik mengenai ketidakpastian lingkungan, strategi inovasi, kinerja organisasi dan modal intelektual pada dasarnya merupakan topik yang selalu menarik untuk diteliti karena selaras dengan fenomena yang dihadapi oleh berbagai entitas. Strategi inovasi menjadi faktor utama untuk memenangkan kompetisi sehingga berdampak pada kinerja perusahaan (Hariyati \& Tjahjadi, 2014). Prajogo (2016) juga meneliti topik yang serupa tetapi dengan mempertimbangkan kondisi lingkungan yang sedang dihadapi oleh perusahaan dimana lingkungan bisnis merupakan salah satu faktor yang dianggap memiliki peran penting dalam memilih strategi inovasi. Penelitian tersebut memiliki kesamaan dalam hal menilai kinerja perusahaan, namun masih terbatas pada faktor kinerja keuangan. Sehubungan dengan itu, penelitian ini menambahkan faktor lain yaitu mengkombinasikan kinerja keuangan dan kinerja non-keuangan dalam menilai kinerja perusahaan agar diperoleh informasi yang lebih komprehensif tentang kinerja. Berkenaan dengan hal itu, penelitian sebelumnya juga belum sepenuhnya konklusif terkait peran strategi inovasi terhadap kinerja perusahaan. Prajogo (2016) menunjukkan bahwa tidak semua inovasi dapat meningkatkan kinerja karena tergantung pada kondisi yang dihadapi, sedangkan Hilman \& Kaliappen (2015) membuktikan bahwa strategi inovasi dapat membantu meningkatkan kinerja perusahaan.

Berdasarkan penjelasan mengenai keterkaitan antara ketidakpastian lingkungan, strategi, dan modal intelektual dalam mencapai kinerja organisasi serta kesenjangan hasil penelitian terdahulu, maka penelitian ini bertujuan untuk menguji kembali peran tersebut dengan menyusun skema ada atau tidaknya hubungan langsung antara ketidakpastian lingkungan dengan strategi yang dipilih dan kinerja organisasi. Disamping itu, adanya kesenjangan penelitian terdahulu membuka peluang untuk menemukan faktor lain yang dapat memengaruhi kinerja. Salah satu faktor adalah dengan menempatkan modal intelektual sebagai variabel pemediasi yang dapat menjadi perantara strategi inovasi dan kinerja organisasi. Sehubungan dengan hal tersebut, penelitian ini diharapkan dapat menjadi pelengkap penelitian sebelumnya.

Untuk memperjelas hubungan diantara beberapa faktor yang diteliti, terdapat beberapa teori yang digunakan pada penelitian ini yaitu teori kontinjensi yang cukup relevan apabila dikaitkan dengan penelitian ini dimana teori kotinjensi dapat didefinisikan sebagai teori yang mengharuskan entitas untuk mengidentifikasi aspek tertentu dari sistem akuntansi yang dihubungkan dengan kondisi tertentu dan menunjukkan penandingan yang tepat (Otley, 2016). Teori kontinjensi menduga bahwa efektivitas organisasi disebabkan oleh kesesuaian karakteristik organisasi dengan kemungkinan yang mencerminkan situasi yang sedang dihadapi oleh organisasi (Donaldson, 2001). Sama halnya ketika dihubungkan dengan akuntansi manajemen yaitu sistem akuntansi yang diimplementasikan tergantung pada beberapa faktor yang dapat memengaruhi kesesuaian tersebut seperti situasi dan kondisi yang sedang dihadapi (Otley, 1980).

Sebagai upaya untuk menghadapi ketidakpastian lingkungan dan memenangkan persaingan, maka diperlukan sumber daya tertentu sebagaimana yang dijelaskan dalam resource-based theory. Resource-based theory merupakan teori yang menjelaskan dan memprediksi dasar keunggulan kompetitif dan kinerja (Barney, Ketchen \& Wright, 2011; Slotegraaf, 2004; Vorhies \& Morgan, 2005). Sebuah perusahaan dapat meraih keunggulan kompetitif ketika dapat menciptakan nilai ekonomi lebih besar daripada rata-rata nilai yang dihasilkan perusahaan lain dalam satu industri. Disamping itu, perusahaan lain tidak mampu meniru strategi yang digunakan (Barney \& Clark, 2007). Setidaknya terdapat 2 asumsi dasar yang menjelaskan tentang penciptaan keunggulan kompetitif dan kinerja 
suatu perusahaan melebihi kinerja perusahaan yang lain yaitu memiliki sumber daya yang berbeda dan perbedaan tersebut dapat dipertahankan.

Kepemilikan sumber daya yang memadai saja tidak cukup dalam menghadapi dinamika bisnis yang ada karena diperlukan sumber daya yang berbeda dan mampu menciptakan keunggulan kompetitif bagi perusahaan seperti pengetahuan atau dapat diwujudkan dalam modal intelektual yang didukung oleh knowledge-based theory. Knowledge-based theory berfokus pada proses atau jalur dimana kemampuan khusus perusahaan dapat berkembang dan dikembangkan dari waktu ke waktu melalui proses pembelajaran yang dipandang sebagai elemen pokok dalam mencapai keunggulan kompetitif (Danneels, 2002; McEvily \& Chakravarthy, 2002). Antara resource-based dan knowledge-based theory memiliki keterkaitan dalam hal sumber daya. Resource-based theory menduga bahwa karakteristik untuk perusahaan berasal dari sumber daya tidak berwujud (khususnya pengetahuan), sedangkan knowledge-based theory mengutamakan pentingnya keunggulan kompetitif yang berkelanjutan karena sumber daya tersebut sulit ditiru sehingga dapat menjadi dasar untuk diferensiasi berkelanjutan (Wiklund \& Shepherd, 2003).

Keterkaitan antara strategi inovasi, ketidakpastian lingkungan, kinerja organisasi dan modal intelektual pada dasarnya dapat ditelusuri berdasarkan penelitian terdahulu atau teori-teori yang mampu menjelaskan hubungan keempat hal tersebut. Sebagai contoh, pada saat konteks lingkungan yang dihadapi sangat tidak pasti dan tidak dapat diprediksi, maka organisasi akan cenderung mendesak atau berupaya semaksimal mungkin untuk dapat menurunkan ketidakpastian tersebut dengan cara merespon kondisi tersebut melalui berbagai upaya yaitu: memilih strategi yang tepat, menyetujui adanya penggunaan sumber daya yang dapat menciptakan nilai serta meningkatkan koordinasi dan kebersamaan (Oliver, 1991). Hal tersebut berarti organisasi akan merespon sebaik mungkin ketika dihadapkan pada berbagai macam tekanan terutama yang mengandung unsur ketidakpastian yang tinggi. Hal tersebut sejalan dengan teori kontinjensi dimana strategi atau kemampuan perusahaan harus diselaraskan dengan karakteristik lingkungan organisasi.

Untuk menghadapi ketidakpastian lingkungan seperti itu, para pelaku bisnis khususnya manajer memerlukan kemampuan yang dinamis, usaha yang lebih keras untuk merespon dengan cepat serta meningkatkan kesadaran terkait peluang pada ketidakpastian tersebut. Respon yang dapat dilakukan oleh manajer bisa beragam seperti mengelola ketidakpastian dengan mengembangkan produk baru (Teece \& Leih, 2016) dimana pengembangan produk sangat berhubungan dengan strategi perusahaan dalam berinovasi. $\mathbf{H}_{\mathbf{1}}$ : Ketidakpastian lingkungan berpengaruh langsung secara positif terhadap penggunaan strategi
inovasi.

Kondisi yang tidak pasti mengharuskan perusahaan untuk mempersiapkan langkah-langkah tertentu sesuai dengan kapasitas yang dimiliki. Hal ini sebagaimana dijelaskan dalam teori kontinjensi bahwa setiap organisasi perlu menyesuaikan kondisi yang sedang dihadapi dengan karakteristik organisasi agar tercapai kinerja yang efektif. Lingkungan yang tidak pasti atau dinamis dapat juga dihubungkan dengan konteks yang bermacam-macam dimana salah satunya adalah ketatnya persaingan pasar yang disebabkan oleh teknologi modern, deregulasi ekonomi dan privatisasi (Bromwich, 1990). Saat perusahaan berada dalam lingkungan dengan kompetisi yang ketat, perusahaan perlu meraih dan mempertahankan keunggulan kompetitif sehingga perusahaan dapat beradaptasi dengan cepat (Senge, 1990). Respon perusahaan dapat diwujudkan dengan melakukan produksi yang lebih inovatif dan disesuaikan dengan kebutuhan pasar (Tripsas, 2008). Untuk menghasilkan produk yang inovatif, diperlukan kombinasi kecanggihan teknologi dan pengetahuan yang memadai agar dapat meningkatkan kemampuan perusahaan dalam berinovasi dan berdampak pada terciptanya keunggulan kompetitif sehingga kinerja perusahaan dapat meningkat yang ditunjukkan dengan peningkatan pangsa pasar dan profitabilitas (Zahra \& Covin, 1993).

$\mathbf{H}_{2}$ : Ketidakpastian lingkungan berpengaruh langsung secara positif terhadap kinerja organisasi.

Organisasi yang dituntut untuk beradaptasi dengan lingkungan dan berkompetisi dengan para pesaing harus dapat menyusun pilihan strategis (Miles \& Snow, 2003). Berdasarkan resource-based theory, kesuksesan strategi inovasi dapat memberikan kinerja yang sangat baik karena inovasi dapat memberikan nilai tambah bagi pelanggan, memiliki perbedaan dibandingkan pesaing, relatif sulit untuk ditiru dan tidak dapat digantikan (Barney, 1991; Peteraf, 1993; Wernerfelt, 1984). Strategi inovasi dapat dipandang dari dua perspektif yaitu strategi inovasi produk dan proses dimana masing-masing memiliki kelebihan dan keistimewaan. Kelebihan tersebut memungkinkan perusahaan untuk meraih dan mempertahankan keunggulan kompetitif. Ketika perusahaan dapat menemukan keunggulan yang tidak dapat ditiru dengan mudah, maka perusahaan akan mendapatkan banyak manfaat.

$\mathbf{H}_{3}$ : Penggunaan strategi inovasi berpengaruh langsung secara positif terhadap kinerja organisasi. 
Untuk dapat berinovasi, perusahaan harus dapat mengoptimalkan sumber daya yang dimiliki seperti modal intelektual. Sesuai dengan penjelasan pada knowledge-based theory yang menyebutkan bahwa untuk dapat mewujudkan keunggulan kompetitif yang ada pada modal intelektual, maka diperlukan proses yang dapat menjadikan perusahaan terus berkembang dimana salah satunya dari strategi inovasi yang telah ditetapkan. Keterkaitan antara strategi inovasi dan modal intelektual telah diteliti oleh Hariyati \& Tjahjadi (2014) yang menunjukkan adanya hubungan positif antara strategi inovasi dan modal intelektual dimana perusahaan membutuhkan modal intelektual dalam penerapan strategi. Hasil penlitian ini konsisten dengan hasil penelitian dari Harrison \& Sullivan (2000) yang menemukan bahwa kesuksesan perusahaan terkait peningkatan kinerja bergantung pada usaha rutin perusahaan dalam mengoptimalkan nilai yang terkandung dalam modal intelektual.

$\mathbf{H}_{4}$ : Penggunaan strategi inovasi berpengaruh langsung secara positif terhadap modal intelektual.

Modal intelektual dianggap sebagai modal yang mampu menyediakan sumber daya dan kemampuan untuk menghasilkan keunggulan kompetitif melalui tiga komponen yaitu human capital, structural capital dan relational capital. Berdasarkan resource-based theory, sumber daya internal seperti sumber daya intelektual yang tidak berwujud memiliki nilai, sulit untuk ditiru dan memiliki peran yang sangat penting untuk memperoleh keunggulan kompetitif yang berkelanjutan (Kamukama, 2013). Penelitian yang dilakukan oleh Chen et al. (2005) menunjukkan bahwa modal intelektual yang dimiliki oleh perusahaan berpengaruh positif terhadap kinerja perusahaan. Penelitian yang dilakukan oleh Kalkan et al. (2014) juga menemukan bahwa structural capital yang dicerminkan oleh jumlah pengeluaran untuk penelitian dan pengembangan memiliki pengaruh yang positif terhadap nilai perusahaan dan profitabilitas.

$\mathbf{H}_{5}$ : Modal intelektual berpengaruh langsung secara positif terhadap kinerja organisasi.

Berdasarkan penjelasan pada hipotesis 3 dan hipotesis 5, dapat diketahui bahwa strategi inovasi maupun modal intelektual diduga dapat memberikan pengaruh yang positif terhadap kinerja organisasi. Kedua variabel tersebut pada dasarnya dapat saling dikaitkan karena inovasi dapat terlaksana dengan dukungan dari modal intelektual yang terdiri dari human capital, structural capital dan customer capital. Penelitian yang dilakukan oleh Gloet \& Terziovski (2004) menjelaskan bahwa peran sumber daya manusia sangat penting dalam membangun strategi inovasi untuk produk maupun proses. Pengelolaan yang baik terhadap sumber daya manusia dan ditunjang dengan manajemen pengetahuan diharapkan dapat semakin meningkatkan efektivitas strategi yang telah dipilih. Sehubungan dengan itu, perusahaan perlu mempertimbangkan modal intelektual apa saja yang dibutuhkan dalam menerapkan strategi yang telah dipilih untuk mencapai kinerja yang telah ditargetkan (Hariyati \& Tjahjadi, 2014). Dengan kata lain, modal intelektual berperan sebagai pemediasi yang menghubungkan kedua komponen tersebut pada konteks strategi inovasi dan kinerja organisasi.

$\mathbf{H}_{6}$ : Penggunaan strategi inovasi berpengaruh secara positif terhadap kinerja organisasi melalui mediasi modal intelektual.

\section{METODE}

Penelitian ini menggunakan pendekatan kuantitatif yang bertujuan untuk menguji pengaruh ketidakpastian lingkungan terhadap strategi inovasi dan kinerja organisasi serta menguji efek mediasi modal intelektual terhadap hubungan strategi inovasi dan kinerja organisasi. Populasi pada penelitian ini adalah perusahaan yang ada di wilayah Gresik khususnya pada industri manufaktur, dengan pertimbangan bahwa Gresik merupakan salah satu wilayah pusat industri di Jawa Timur. Secara spesifik, metode yang digunakan adalah survei melalui kuesioner yang disebarkan kepada sampel penelitian dengan teknik purposive sampling. Sampel yang dipilih berdasarkan kriteria tertentu seperti memiliki posisi sebagai staf atau manajer dan memiliki pengalaman kerja minimal dua tahun. Berdasarkan kriteria tersebut, diperoleh 55 sampel penelitian yang berasal dari 29 perusahaan. Penentuan kriteria dimaksudkan agar responden pada penelitian ini memiliki pemahaman dan pengetahuan yang memadai tentang informasi yang ditanyakan pada kuesioner khususnya pada pertanyaan yang berkaitan dengan variabel strategi dimana pertanyaan-pertanyaan mengenai strategi diharapkan dapat dijawab dengan tepat oleh pihak yang telah memahami kondisi perusahaan.

\section{Definisi Operasional Variabel}

Strategi inovasi digunakan untuk mengukur sejauh mana strategi tersebut diterapkan pada suatu organisasi yang meliputi strategi inovasi produk dan proses. Variabel strategi inovasi diukur melalui menggunakan beberapa pertanyaan mengacu pada penelitian Prajogo (2016) dengan skala likert dari 1 hingga 5. Ketidakpastian lingkungan diukur berdasarkan beberapa aspek tentang persepsi responden 
terhadap beberapa hal yang meliputi prediktabilitas dan stabilitas pada berbagai macam aspek lingkungan organisasi termasuk lingkungan industri, ekonomi, teknologi dan pelanggan. Pertanyaan yang diajukan kepada responden diukur dengan menggunakan skala likert dari 1 hingga 5 yang menunjukkan ketidakpastian paling rendah hingga paling tinggi (Gordon \& Narayanan, 1984). Modal intelektual yang digunakan pada penelitan ini terdiri dari 3 unsur yaitu human capital, social capital dan organizational capital. Setiap unsur diukur berdasarkan beberapa komponen yang diadopsi dari penelitian Bontis (1998) yaitu 3 komponen untuk human capital, 3 komponen untuk social capital dan 2 komponen untuk organizational capital. Setiap komponen pengukuran yang mencerminkan tiga unsur modal intelektual ditanyakan kepada responden melalui kuesioner yang telah dirancang dengan menggunakan skala likert 1 hingga 5. Pengukuran untuk kinerja organisasi mengacu pada penelitian Govindarajan (1984), Mia \& Clarke (1999) yang mengklasifikasikan kinerja menjadi dua jenis kinerja yaitu kinerja keuangan dan kinerja non-keuangan yang dapat mencerminkan pelaksanaan strategi inovasi. Terdapat 10 pengukuran pada kedua jenis kinerja tersebut yaitu: tingkat pertumbuhan penjualan, pangsa pasar, laba operasional, marjin laba, arus kas, return on investment, pengembangan produk baru, pengembangan pasar, penelitian dan pengembangan serta pengembangan pegawai.

\section{Teknik Analisis Data}

Teknik analisis data pada penelitian ini menggunakan teknik PLS (Patial Least Square) dengan aplikasi SmartPLS yang dilakukan melalui dua tahap yaitu mengevaluasi model pengukuran (outer model) dan mengevaluasi model struktural (inner model) (Abdillah \& Hartono, 2015). Model pengukuran atau outer model digunakan untuk menguji validitas dan reliabilitas instrumen. Model struktural atau inner model dievaluasi dengan mengamati nilai indeks Goodness of Fit (GoF) (Tenenhaus et al., 2004). Disamping itu, analisis data juga dilakukan untuk menguji efek mediasi dari modal intelektual melalui beberapa tahap yaitu: 1) menguji efek utama (pengaruh variabel independen terhadap variabel dependen) yang hasilnya harus signifikan; 2) menguji pengaruh variabel independen terhadap variabel mediasi yang hasilnya harus signifikan; 3) menguji secara simultan efek utama dan pengaruh variabel mediasi terhadap variabel dependen dimana diharapkan hasil pengujian efek utama akan menjadi tidak signifikan, sedangkan pengaruh variabel mediasi terhadap variabel dependen menjadi signifikan (Hartono \& Abdillah, 2014).

\section{HASIL DAN PEMBAHASAN}

\section{Analisis Outer Model}

Analisis outer model terdiri dari dua pengujian yaitu uji validitas dan reliabilitas. Untuk uji validitas dikategorikan menjadi dua pengujian yaitu uji validitas konvergen dan uji validitas diskriminan.

\section{Validitas konvergen}

Suatu indikator konstruk dapat dianggap memenuhi validitas konvergen apabila memiliki nilai loading lebih besar dari 0,5. Hasil pengujian validitas konvergen pada penelitian ini dapat dilihat pada Tabel 1. Berdasarkan hasil pengujian validitas konvergen, seluruh indikator memiliki nilai loading > 0,5. Hal ini dapat diinterpretasikan bahwa indikator telah memenuhi validitas konvergen.

\section{Validitas diskriminan}

Pengujian validitas diskriminan pada penelitian ini menggunakan perbandingan antara $\sqrt{A V E}$ dengan korelasi antar konstruk ( $\sqrt{A V E}$ lebih dari korelasi variabel laten). Hasil pengujian validitas diskriminan dapat dilihat pada Tabel 2. Tabel 2 menunjukkan bahwa nilai setiap konstruk lebih besar dari seluruh korelasi variabel laten. Hasil ini mengindikasikan bahwa seluruh indikator memenuhi validitas diskriminan.

\section{Reliabilitas}

Uji reliabiltias dilakukan dengan mengamati nilai cronbach's alpha dan composite reliability. Suatu konstruk dapat disimpulkan reliabel jika nilai composite reliability atau nilai cronbach's alpha lebih besar dari 0,7 walaupun nilai 0,6 masih dapat diterima (Hair et al., 2009). Hasil pengujian reliabilitas dapat dilihat pada Tabel 3. Berdasarkan Tabel 3, dapat diketahui bahwa nilai composite reliability>0,7 dan nilai cronbach's alpha>0,6. Hasil tersebut menunjukkan bahwa indikator konstruk telah memenuhi syarat reliabiltas suatu konstruk. 
Tabel 1. Hasil Pengujian Validitas Konvergen

\begin{tabular}{|c|c|c|c|c|}
\hline & KL & KO & MI & SI \\
\hline KL1 & 0,894 & & & \\
\hline KL2 & 0,790 & & & \\
\hline KL3 & 0,638 & & & \\
\hline KO1 & & 0,817 & & \\
\hline KO2 & & 0,773 & & \\
\hline KO3 & & 0,875 & & \\
\hline $\mathrm{KO} 4$ & & 0,862 & & \\
\hline KO5 & & 0,766 & & \\
\hline KO6 & & 0,836 & & \\
\hline KO7 & & 0,786 & & \\
\hline KO8 & & 0,815 & & \\
\hline KO9 & & 0,743 & & \\
\hline KO10 & & 0,746 & & \\
\hline MI1 & & & 0,783 & \\
\hline MI2 & & & 0,785 & \\
\hline MI3 & & & 0,801 & \\
\hline MI4 & & & 0,845 & \\
\hline MI5 & & & 0,721 & \\
\hline MI6 & & & 0,727 & \\
\hline MI7 & & & 0,790 & \\
\hline MI8 & & & 0,848 & \\
\hline SI1 & & & & 0,879 \\
\hline SI2 & & & & 0,797 \\
\hline SI3 & & & & 0,834 \\
\hline SI 4 & & & & 0,882 \\
\hline SI5 & & & & 0,844 \\
\hline
\end{tabular}

Tabel 2. Hasil Pengujian Validitas Diskriminan

\begin{tabular}{lccccc}
\hline & $\sqrt{\text { AVE }}$ & KL & KO & MI & SI \\
\hline KL & 0,781 & 1 & 0,714 & 0,323 & 0,368 \\
KO & 0,803 & 0,714 & 1 & 0,483 & 0,406 \\
MI & 0,789 & 0,323 & 0,483 & 1 & 0,587 \\
SI & 0,848 & 0,368 & 0,406 & 0,587 & 1 \\
\hline
\end{tabular}

Tabel 3. Hasil Pengujian Reliabilitas

\begin{tabular}{lcc}
\hline & Composite Reliability & Cronbach's Alpha \\
\hline Ketidakpastian Lingkungan & 0,822 & 0,671 \\
Kinerja Organisasi & 0,948 & 0,938 \\
Modal Intelektual & 0,929 & 0,913 \\
Strategi Inovasi & 0,927 & 0,902 \\
\hline
\end{tabular}

\section{Analisis inner model}

Analisis inner model digunakan untuk pengujian model struktural atau biasa disebut sebagai pengujian untuk goodness of fit (GoF). Nilai atau indeks GoF dapat dihitung menggunakan rumus 
$\sum \sqrt{ }$ AVE $x R^{2}$ (Tenenhaus et al., 2004). Indeks GoF pada penelitian ini sebagaimana terlihat pada Tabel 4. Berdasarkan indeks GoF yang tertera pada Tabel 4, dapat diketahui bahwa model penelitian ini merupakan model dengan kategori yang baik dengan nilai 0,479 .

\section{Pengujian Hipotesis}

Hasil pengujian hipotesis 1 dan hipotesis 2 dapat dilihat pada Tabel 5. Tabel 5 menunjukkan bahwa hipotesis 1 terdukung yang berarti ketidakpastian lingkungan berpengaruh positif terhadap strategi inovasi. Tabel 5 juga menunjukkan hipotesis 2 terdukung yang berarti ketidakpastian lingkungan berpengaruh positif terhadap kinerja organisasi. Pengujian hipotesis 3 yaitu pengaruh strategi inovasi terhadap kinerja organisasi dapat dilihat pada Tabel 6.

Langkah pertama dalam pengujian efek mediasi yaitu menguji efek utama (strategi inovasi terhadap kinerja organisasi). Berdasarkan Tabel 6, dapat diketahui bahwa efek utama atau hipotesis 3 terdukung yaitu strategi inovasi berpengaruh positif terhadap kinerja organisasi. Hasil ini menunjukkan bahwa syarat utama pengujian efek mediasi telah terpenuhi. Selanjutnya, Tabel 7 menunjukkun pengujian hipotesis 4 yaitu pengaruh strategi inovasi terhadap modal intelektual.

Tabel 7 menunjukkan bahwa hipotesis 4 terdukung yaitu strategi inovasi berpengaruh positif terhadap modal intelektual. Hasil ini membuktikan bahwa syarat kedua pengujian efek mediasi yaitu pengujian variabel independen terhadap variabel pemediasi yang harus signifikan telah terpenuhi. Hasil uji hipotesis 5 yang berbunyi pengaruh modal inteketual terhadap kinerja organisasi dapat dilihat pada Tabel 8.

Tabel 4. Indeks GoF

\begin{tabular}{cccc}
\hline & AVE & $\mathbf{R}^{2}$ & \\
\hline KL & 0,610 & & \\
KO & 0,645 & 0,581 & \\
MI & 0,622 & 0,345 & \\
SI & 0,719 & 0,135 & \\
Skor rata-rata & 0,649 & 0,354 & 0,229 \\
AVE $\times \mathrm{R}^{2}$ & & & 0,479 \\
GoF $=\sum \sqrt{\text { AVE } x \mathrm{R}^{2}}$ & & & \\
\hline
\end{tabular}

Tabel 5. Pengujian Hipotesis 1 dan 2

\begin{tabular}{cccc}
\hline & T-Statistics & P Values & Interpretasi \\
\hline KL -> KO & 5,815 & $\mathbf{0 , 0 0 0 * *}$ & Hipotesis 1 terdukung \\
KL -> SI & 2,472 & $\mathbf{0 , 0 1 4 *}$ & Hipotesis 2 terdukung \\
\hline$*=$ signifikan pada level $5 \%$ & & \\
$* *=$ signifikan pada level $1 \%$ & & \\
\hline
\end{tabular}

Tabel 6. Pengujian Hipotesis Strategi Inovasi terhadap Kinerja Organisasi

\begin{tabular}{cccc}
\hline Indikator & T-Statistics & P Values & Interpretasi \\
\hline SI $->$ KO & 5,256 & $\mathbf{0 , 0 0 0 * *}$ & Hipotesis 3 terdukung \\
\hline$* *=$ signifikan pada level $1 \%$ & & \\
\hline
\end{tabular}

Tabel 7. Pengujian Hipotesis Strategi Inovasi terhadap Modal Intelektual

\begin{tabular}{lccc}
\hline \multicolumn{1}{c}{ Indikator } & T-Statistics & P Values & Interpretasi \\
\hline SI $->$ MI & 7,774 & $\mathbf{0 , 0 0 0}^{* *}$ & Hipotesis 4 terdukung \\
\hline$* *=$ signifikan pada level $1 \%$ & & \\
\hline
\end{tabular}

Tabel 8. Pengujian Hipotesis Modal Intelektual terhadap Kinerja Organisasi

\begin{tabular}{lccl}
\hline \multicolumn{1}{c}{ Indikator } & T-Statistics & P Values & Interpretasi \\
\hline MI $>$ KO & 6,085 & $\mathbf{0 , 0 0 0 * *}$ & Hipotesis 5 terdukung \\
\hline$* *=$ signifikan pada level $1 \%$ & & \\
\hline
\end{tabular}


Tabel 9. Pengujian Hipotesis Strategi Inovasi, Modal Intelektual dan Kinerja Organisasi

\begin{tabular}{lccc}
\hline \multicolumn{1}{c}{ Indikator } & T-Statistics & P Values & Interpretasi \\
\hline MI $>$ KO & 2,770 & $0,007^{* *}$ & H5 terdukung \\
SI $>$ KO & 1,028 & 0,340 & H6 terdukung* \\
SI $>$ MI & 7,035 & $0,000^{* *}$ & H4 terdukung \\
\hline
\end{tabular}

Keterangan:

*Hipotesis 6 terdukung yang dibuktikan dari hasil yang tidak signifikan apabila diuji secara simultan $* *=$ signifikan pada level $1 \%$

Tabel 10. Hasil Pengujian Hipotesis

\begin{tabular}{lll}
\hline & \multicolumn{1}{c}{ Hipotesis } & Hasil \\
\hline 1 & $\begin{array}{l}\text { Ketidakpastian lingkungan berpengaruh langsung secara positif terhadap penggunaan } \\
\text { strategi inovasi }\end{array}$ & Terdukung \\
2 & Ketidakpastian lingkungan berpengaruh langsung secara positif terhadap kinerja organisasi & Terdukung \\
3 & Penggunaan strategi inovasi berpengaruh langsung secara positif terhadap kinerja organisasi & Terdukung \\
4 & Penggunaan strategi inovasi berpengaruh langsung secara positif terhadap modal intelektual & Terdukung \\
5 & Modal intelektual berpengaruh langsung secara positif terhadap kinerja organisasi & Terdukung \\
6 & $\begin{array}{l}\text { Penggunaan strategi inovasi berpengaruh secara positif terhadap kinerja organisasi melalui } \\
\text { mediasi modal intelektual }\end{array}$ & Terdukung \\
\hline
\end{tabular}

Hasil pengujian hipotesis yang tertera pada Tabel 8 menunjukkan nilai signifikansi p-values $<1 \%$ yang berarti hipotesis 5 terdukung yaitu modal intelektual berpengaruh terhadap kinerja organisasi.

Langkah ketiga dari pengujian mediasi adalah untuk membuktikan peran modal intelektual dalam memediasi strategi inovasi dan kinerja organisasi dengan cara menguji secara simultan ketiga variabel tersebut. Namun, sebelum menguji langkah ketiga, hasil pengujian variabel pemediasi terhadap variabel dependen harus diperhatikan terlebih dahulu yaitu terkait pengaruh modal intelektual terhadap kinerja organisasi melalui modal intelektual (Hipotesis 6). Hasil pengujian variabel pemediasi terhadap variabel dependen dapat dilihat pada Tabel 9.

Hasil tidak signifikan pada hipotesis 6 membuktikan bahwa modal intelektual ternyata mampu untuk memediasi secara penuh antara strategi inovasi dan kinerja organisasi. Dalam hal ini, strategi inovasi tidak dapat memengaruhi kinerja organisasi secara langsung ketika terdapat variabel modal intelektual. Hal tersebut berarti hipotesis 6 terdukung. Hasil penelitian dapat disimpulkan dalam Tabel 10.

\section{Ketidakpastian Lingkungan dan Strategi Inovasi}

Hasil pengujian hipotesis pada Tabel 10 menunjukkan bahwa seluruh hipotesis terdukung. Ketidakpastian lingkungan memiliki pengaruh positif terhadap strategi inovasi dan kinerja organisasi. Penelitian ini sesuai dengan penelitian Cao et al. (2012) dan Oliver (1991) yang menyimpulkan bahwa penyusunan strategi setiap perusahaan sangat ditentukan oleh faktor lingkungan yang dihadapi. Namun hasil penelitian ini sedikit berbeda dengan penelitian Wu (2013) yang menunjukkan bahwa tidak semua kondisi lingkungan yang tidak pasti memiliki pengaruh bagi organisasi seperti ketidakpastian dalam hal teknologi yang dimiliki oleh perusahaan.

Hasil penelitian ini juga mendukung teori kontinjensi yang menjelaskan bahwa strategi atau kemampuan perusahaan harus disesuaikan dengan karakteristik lingkungan yang dihadapi oleh perusahaan. Sebagaimana dinamika bisnis, perkembangan bisnis yang semakin kompleks menjadikan lingkungan yang dihadapi oleh perusahaan menjadi sangat tidak pasti dan mengharuskan perusahaan untuk dapat beradaptasi menghadapi kondisi tersebut dengan cara menyusun langkah-langkah strategis dimana misi atau strategi yang diusulkan harus sesuai dengan lingkungan yang dihadapi dan dapat memberikan keunggulan kompetitif bagi perusahaan. Jabnoun et al. (2003) juga berpendapat bahwa strategi, pertimbangan mengenai ketersediaan sumber daya, kemampuan dan kompetensi perusahaan serta kebutuhan pelanggan sangat diperlukan untuk membuat organisasi dapat selaras dengan lingkungan. Beberapa perusahaan tentu sudah mulai menyadari bahwa perusahaan tidak bisa hanya mengandalkan sumber daya yang dimiliki tanpa melakukan langkah inovatif yang dikombinasikan dengan kecanggihan teknologi terutama pada saat ini dimana arus revolusi industri 4.0 menjadi sangat dominan dalam memengaruhi kondisi perusahaan. 


\section{Ketidakpastian lingkungan dan Kinerja Organisasi}

Era revolusi industri 4.0 yang semakin dinamis sejalan dengan konsep awal teori kontinjensi yang menunjukkan bahwa era tersebut menjadi satu prasyarat bagi perusahaan untuk dapat beradaptasi sesuai dengan kondisi yang sedang berkembang. Apabila perusahaan mampu untuk terus menyesuaikan kemampuan perusahaan dengan ketidakpastian lingkungan, maka perusahaan akan mampu untuk memenangkan persaingan yang kemudian dapat berdampak pada peningkatan kinerja organisasi di bidang keuangan dan non-keuangan. Penelitian Hoque (2004) juga menjelaskan bahwa dalam rerangka kontinjensi, organisasi perlu memperhatikan ketidakpastian yang sedang dihadapi oleh perusahaan. Hal ini dapat dilakukan dengan memaksimalkan peran sistem akuntansi manajemen dan strategi dengan harapan agar kinerja organisasi akan terpengaruh sehingga perusahaan dapat menjalankan aktivitas secara efektif dan menghasilkan output kinerja yang selaras dengan langkahlangkah adaptif yang dilakukan oleh perusahaan. Namun hasil penelitian ini tidak sepenuhnya sesuai dengan penelitian Fernandes \& Solimun (2017) yang menyebutkan bahwa ketidakpastian lingkungan tidak selalu menjadi faktor yang menentukan kinerja organisasi.

\section{Strategi Inovasi dan Kinerja Organisasi}

Pemahaman mendalam mengenai tindakan yang harus dipersiapkan oleh perusahaan dapat menjadi penentu berhasil atau tidaknya strategi yang dipilih terhadap kinerja organisasi. Latan et al. (2018) juga berpendapat bahwa ketidakpastian lingkungan yang dihadapi dapat mendorong perusahaan untuk memilih langkah tertentu yang sesuai seperti penggunaan akuntansi manajemen lingkungan. Hilman \& Kaliappen (2015) juga membuktikan bahwa perusahaan memilih strategi inovasi tertentu yaitu inovasi proses dan jasa agar dapat terus bertumbuh di tengah gejolak lingkungan bisnis. Hasil ini mengkonfirmasi resource-based theory yang menjelaskan bahwa perusahaan dapat mencapai kesuksesan jika perusahaan harus memiliki cara yang berbeda dan unik seperti menyusun suatu strategi inovasi. Namun penelitian Karagozoglu (1993) menyajikan hasil penelitian yang menunjukkan bahwa hal-hal yang bersifat unik atau strategis tidak terbukti berdampak pada kinerja melalui penciptaan keunggulan kompetitif. Perbedaan hasil penelitian terdahulu dapat disebabkan oleh faktor lain yang dapat menentukan optimalisasi peran strategi inovasi dan kinerja organisasi. Pada awalnya, strategi inovasi proses dan produk memang dapat langsung menentukan sukses atau tidaknya kinerja suatu perusahaan karena perusahaan yang selalu berinovasi cenderung lebih mudah untuk meraih dan mempertahankan keunggulan kompetitif. Aghajari \& Senin (2014) juga menyatakan peningkatan kinerja keuangan maupun kinerja operasional harus disertai pemahaman inovasi sesuai dengan situasi dan kondisi yang dihadapi. Akan tetapi, ketika diujikan secara simultan dengan modal intelektual, pengaruh strategi inovasi terhadap kinerja organisasi menjadi tidak signifikan. Hal ini mengindikasikan bahwa untuk dapat mengambil keputusan dengan cepat dan tepat, perusahaan harus selalu mertimbangkan faktor-faktor yang menentukan keberhasilan, misalnya pemilihan strategi inovasi harus memperhitungkan sumber daya atau pihak-pihak yang akan menjalankan strategi tersebut.

\section{Strategi Inovasi dan Modal Intelektual}

Untuk mencapai keunggulan kompetitif yang dapat meningkatkan kinerja organisasi, pemilihan dan implementasi strategi inovasi saja tidak cukup, tetapi harus ditunjang dengan sumber daya yang nantinya akan menjalankan dan mengelola strategi yang telah dipilih. Sebagaimana hasil yang ditunjukkan pada hipotesis keempat, pemaksimalan strategi harus disertai dengan modal intelektual yang memadai karena modal intelektual adalah sumber daya yang mampu menciptakan keistimewaan tertentu bagi perusahaan. Hasil pengujian hipotesis keempat mendukung knowledge-based theory yang mengutamakan keunggulan kompetitif karena sulit ditiru seperti penyusunan strategi inovasi yang unik sehingga dapat dimaksimalkan oleh sumber daya yang ada pada perusahaan. Pengaruh strategi inovasi terhadap modal intelektual juga sesuai dengan penelitian Rexhepi et al. (2013) yang menunjukkan bahwa untuk dapat memaksimalkan fungsi modal intelektual, diperlukan strategi yang tepat agar dapat mentransformasikan modal intelektual pada setiap individu menjadi suatu nilai yang bermanfaat bagi perusahaan.

\section{Modal Intelektual dan Kinerja Organisasi}

Pengujian hipotesis kelima menunjukkan bahwa modal intelektual memiliki pengaruh langsung terhadap kinerja organisasi. Hasil ini mendukung resource-based theory dan knowledge-based theory yang menjelaskan bahwa sumber daya yang tidak berwujud merupakan modal yang dapat memberikan kontribusi bagi perusahaan dengan menciptakan suatu keunggulan yang tidak mudah 
ditiru. Disamping itu, beberapa penelitian terdahulu seperti penelitian Gogan et al. (2016); Lee \& Lin (2019); Liu (2017); Sardo et al. (2018) juga menyajikan hasil yang serupa, yaitu modal intelektual sebagai salah satu penentu keberhasilan suatu perusahaan terutama pada social capital karena modal tersebut dapat menimbulkan kepercayaan dalam organisasi, meningkatkan inovasi dan memperluas jejaring organisasi sehingga dapat menjadikan organisasi menjadi lebih baik di bidangnya. Akan tetapi, sebagian besar penelitian tersebut menilai modal intelektual dengan cara mengkuantifikasikan beberapa komponen modal intelektual sedangkan modal intelektual dalam penelitian ini dinilai dengan mempertimbangkan faktor-faktor yang tidak selalu dapat dikuantifikasikan.

\section{Strategi Inovasi, Modal Intelektual dan Kinerja Organisasi}

Berbeda dengan penelitian Latan et al. (2018) yang menggunakan akuntansi manajemen lingkungan sebagai faktor yang dapat memediasi strategi dan kinerja, penelitian ini menekankan peran modal intelektual. Kuatnya pengaruh modal intelektual juga mendukung hipotesis yang menyatakan bahwa modal intelektual ternyata mampu untuk memediasi strategi inovasi dan kinerja organisasi. Hal tersebut berarti strategi inovasi dapat memberikan pengaruh terhadap kinerja organisasi apabila ditunjang dari sumber daya atau modal intelektual yang memadai. Tanpa adanya modal intelektual, strategi hanya menjadi langkah awal yang belum dapat berdampak bagi kinerja suatu organisasi. Hasil ini diperkuat dari dasar teori yang digunakan yaitu resource-based theory dan knowledgebased theory sebagaimana yang telah dijelaskan pada perumusan hipotesis yang menekankan bahwa perusahaan dapat mencapai keunggulan kompetitif apabila memiliki sumber daya berkarakteristik unik dan sulit ditiru. Penelitian lain juga mengkonfirmasi hasil yang serupa seperti penelitian Chen et al. (2005) serta Kalkan et al. (2014) yang menyimpulkan bahwa modal intelektual dapat menentukan kinerja organisasi secara signifikan khususnya kinerja keuangan. Peran tersebut disebabkan karena komponen modal intelektual yang meliputi human capital, structural capital dan organizational capital dimana masing-masing komponen tersebut mencakup aspek-aspek penting bagi keberhasilan organisasi dan apabila dikombinasikan dengan baik akan tercapai suatu keunggulan kompetitif. Oleh karena itu, perumusan strategi inovasi harus ditunjang oleh kemampuan sumber daya dan modal intelektual perusahaan agar strategi inovasi dapat diimplementasikan secara optimal dan menghasilkan keunggulan yang unik dan berdaya saing.

\section{SIMPULAN}

Penelitian ini berhasil membuktikan bahwa seluruh hipotesis diterima yaitu ketidakpastian lingkungan berpengaruh terhadap strategi inovasi dan kinerja organisasi, strategi inovasi berpengaruh terhadap kinerja organisasi dan modal intelektual serta modal intelektual terbukti mampu memediasi hubungan antara strategi inovasi dan kinerja organisasi. Masing-masing variabel berperan dalam menentukan keberhasilan suatu organisasi dimana ketidakpastian lingkungan menjadi faktor yang penting dalam menyusun suatu strategi dan menjadi faktor yang penting untuk dipertimbangkan agar kinerja organisasi menjadi lebih baik. Disamping itu, perusahaan harus mengoptimalkan sumber daya yang dimiliki khususnya modal intelektual agar strategi yang disusun dapat berdampak positif bagi kinerja perusahaan.

Hasil tersebut mendukung teori-teori yang berhubungan dengan kinerja organisasi, seperti teori kontinjensi, resource-based theory, knowledge-based theory dan industrial organizational theory dimana teori-teori tersebut menjelaskan bahwa keberhasilan suatu organisasi ditentukan oleh berbagai faktor yang meliputi faktor internal (strategi inovasi dan modal intelektual) dan faktor eksternal (kondisi lingkungan bisnis yang penuh dengan ketidakpastian). Berdasarkan hasil tersebut, maka penelitian ini dapat memberikan implikasi bagi para pengambil keputusan di perusahaan untuk terus mewaspadai gejolak bisnis yang sedang terjadi. Perusahaan juga wajib memperhatikan dan mengoptimalkan modal intelektual yang dimiliki agar dapat tercipta keunggulan kompetitif dan mampu bersaing secara berkelanjutan.

Keseluruhan hasil penelitian yang mendukung hipotesis tidak terlepas dari keterbatasan yang ada pada penelitian ini yaitu tidak mempertimbangkan variabel-variabel lain yang mungkin dapat menjadi penentu kinerja organisasi. Disamping itu, jumlah responden penelitian relatif sedikit serta peran modal intelektual tidak diuji dengan lebih spesifik sesuai dengan komponennya. Penelitian selanjutnya diharapkan dapat memperluas sampel penelitian dan menambahkan faktor-faktor lain yang tidak dibahas pada penelitian ini seperti sistem akuntansi manajemen dan sistem pengendalian manajemen yang ada pada perusahaan. 


\section{DAFTAR RUJUKAN}

Abdillah, W. \& Hartono, J. (2015). Partial Least Square (PLS): Alternatif Structural Equation Modeling (SEM) dalam Penelitian Bisnis. Jakarta: Andi.

Aghajari, N. \& Senin, A. A. (2014). Strategic Orientation and Dual Innovative Operation Strategies: Implications for Performance of Manufacturing SMEs. Asia-Pacific Journal of Business Administration, 6(2), 127-147. doi:10.1108/APJBA-07-2013-0075.

Barney, J. (1991). Firm Resources and Sustained Competitive Advantage. Academy of Management Review, 171), 99-120. doi:10.1177\%2F014920639101700108.

Barney, J. B. \& Clark, D. N. (2007). Resource-Based Theory: Creating and Sustaining Competitive Advantage. New York: Oxford University Press Inc.

Barney, J. B., Ketchen, D. J., \& Wright, M. (2011). The Future of Resource-Based Theory: Revitalization or Decline?. Journal of Management, 37(5), 1299-1315. doi:10.1177/0149206310391805.

Bhattacharjee, S., Moreno, K. K., \& Salbador, D. A. (2015). The Impact of Multiple Tax Returns on Tax Compliance Behavior. Behavioral Research in Accounting, 27(1), 99-119. doi:10.2308/ bria-50976.

Bontis, N. (1998). Intellectual capital: An Exploratory Study that Develops Measures and Models. Management Decision, 36(2), 63-76. doi:10.1108/00251749810204142.

Bontis, N., Chua Chong Keow, W., \& Richardson, S. (2000). Intellectual Capital and Business Performance in Malaysian Industries. Journal of Intellectual Capital, 1(1), 85-100. doi:10.1108/14691930010324188.

Bromwich, M. (1990). The Case for Strategic Management Accounting: The Role of Accounting Information for Strategy in Competitive Markets. Accounting; Organisations and Society, 15(1/2), 27-46. doi:10.1016/0361-3682(90)90011-I.

Cao, Q., Baker, J., \& Hoffman, J. J. (2012). The Role of The Competitive Environment in Studies of Strategic Alignment: A Meta-Analysis. International Journal of Production Research, 50(2), 567-580. doi:10.1080/00207543.2010.538742.

Caruana, A., Ewing, M. T., \& Ramaseshan. (2002). Effects of Some Environmental Challenges and Centralization on The Entrepreneurial Orientation and Performance of Public Sector Entities. The Service Industries Journal, 22(2), 43-58. doi:10.1080/714005076.

Chen Goh, P. (2005). Intellectual Capital Performance of Commercial Banks in Malaysia. Journal of Intellectual Capital, 6(3), 385-396. doi:10.1108/14691930510611120.

Chen, M., Cheng, S., \& Hwang, Y. (2005). An Empirical Investigation of The Relationship Between Intellectual Capital and Firms' Market Value and Financial Performance. Journal of Intellectual Capital, 6(2), 159-176. doi:10.1108/14691930510592771.

Colvin, G. (2012). Business's Real Problem: Uncertainty, Uncertainty, Uncertainty. Fortune. 16 November 2018 (11:18).

Danneels, E. (2002). The Dynamics of Product Innovation and Firm Competences: The Dynamics of Product Innovation. Strategic Management Journal, 23(12), 1095-1121. doi:10.1002/smj.275

Del Canto, J. G., \& González, I. S. (1999). A Resource-Based Analysis of The Factors Determining a Firm's R\&D Activities. Research Policy, 28(8), 891-905. doi:10.1016/S0048-7333(99)00029-3.

Donaldson, L. (2001). The Contingency Theory of Organizations. California: Sage Publications Ltd.

Fernandes, A. A. R., \& Solimun. (2017). Moderating Effects Orientation and Innovation Strategy on The Effect of Uncertainty on The Performance of Business Environment. International Journal of Law and Management, 59(6), 1211-1219. doi:10.1108/IJLMA-10-2016-0088.

Gloet, M. \& Terziovski, M. (2004). Exploring The Relationship Between Knowledge Management Practices and Innovation Performance. Journal of Manufacturing Technology Management, 15(5), 9. doi: 10.1108/17410380410540390.

Gogan, L. M., Artene, A., Sarca, I., \& Draghici, A. (2016). The Impact of Intellectual Capital on Organizational Performance. Procedia - Social and Behavioral Sciences, 221, 194-202. doi:10.1016/j.sbspro.2016.05.106. 
Gordon, L. A., \& Narayanan, V. K. (1984). Management Accounting Systems, Perceived Environmental Uncertainty and Organization Structure: An Empirical Investigation. Accounting, Organizations, and Society, 9(1), 33-47. doi:10.1016/0361-3682(84)90028-X.

Govindarajan, V. (1984). Appropiateness of Accounting Data in Performance Evaluation: An Empirical Examination of Environmental Uncertainty as an Intervening Variable. Accounting, Organizastion and Society, 9(2), 125-135. doi:10.1016/0361-3682(84)90002-3.

Hair, J. F., Black, W. C., Babin, B. J., \& Anderson, R. E. (2009). Multivariate Data Analysis: A Global Perspective (7th ed.). New Jersey: Prentice Hall.

Hariyati \& Tjahjadi, B. (2014). Hubungan Antara Strategi Inovasi dengan Kinerja Keuangan yang Dimediasi oleh Modal Intelektual dan Kinerja Pelanggan. Konferensi Regional Akuntansi, II.

Harrison, S. \& Sullivan, P. H. (2000). Profiting from Intellectual Capital. Journal of Intellectual Capital, 1(1), 33-46. doi:10.1108/14691930010324124.

Hartono, J. \& Abdillah, W. (2014). Konsep dan Aplikasi PLS (Partial Least Square) untuk Penelitian Empiris. Yogyakarta: BPFE.

Hilman, H. \& Kaliappen, N. (2015). Innovation Strategies and Performance: Are They Truly Linked?. World Journal of Entrepreneurship, Management and Sustainable Development, 11(1), 48-63. doi:10.1108/WJEMSD-04-2014-0010.

Hoque, Z. (2004). A Contingency Model of The Association Between Strategy, Environmental Uncertainty and Performance Measurement: Impact on Organizational Performance. International Business Review, 13(4), 485-502. doi:10.1016/j.ibusrev.2004.04.003.

Jabnoun, N., Khalifah, A., \& Yusuf, A. (2003). Environmental Uncertainty, Strategic Orientation, and Quality Management: A Contingency Model. Quality Management Journal, 10(4), 17-31. doi: 10.1080/10686967.2003.11919081.

Kalkan, A., Bozkurt, Ö. Ç., \& Arman, M. (2014). The Impacts of Intellectual Capital, Innovation and Organizational Strategy on Firm Performance. Procedia - Social and Behavioral Sciences, 150, 700-707. doi:10.1016/j.sbspro.2014.09.025.

Kamukama, N. (2013). Intellectual capital: Company's Invisible Source of Competitive Advantage. Competitiveness Review, 23(3), 260-283. doi:10.1108/10595421311319834.

Karagozoglu, N. (1993). Environmental Uncertainty, Strategic Planning, and Technological Competitive Advantage. Technovation, 13(6), 335-347. doi:10.1016/0166-4972(93)90075-7.

Latan, H., Chiappetta Jabbour, C. J., Lopes de Sousa Jabbour, A. B., Wamba, S. F., \& Shahbaz, M. (2018). Effects of Environmental Strategy, Environmental Uncertainty and Top Management's Commitment on Corporate Environmental Performance: The Role of Environmental Management Accounting. Journal of Cleaner Production, 180, 297-306. doi:10.1016/j. jclepro.2018.01.106.

Lee, C.-C., \& Lin, C.-K. (2019). The Major Determinants of Influencing The Operating Performance from The Perspective of Intellectual Capital: Evidence on CPA Industry. Asia Pacific Management Review, 24(2), 124-139. doi:10.1016/j.apmrv.2018.01.006.

Liu, C.-H. (2017). The Relationships among Intellectual Capital, Social Capital, and PerformanceThe Moderating Role Of Business Ties and Environmental Uncertainty. Tourism Management, 61, 553-561. doi:10.1016/j.tourman.2017.03.017.

McEvily, S. K., \& Chakravarthy, B. (2002). The Persistence of Knowledge-Based Advantage: An Empirical Test for Product Performance and Technological Knowledge. Strategic Management Journal, 23(4), 285-305. doi:10.1002/smj.223.

Mia, L. \& Clarke, B. (1999). Market Competition, Management Accounting Systems and Business Unit Performance. Management Accounting Research, 10(2), 137-158. doi:10.1006/mare.1998.0097

Miles, R. E. \& Snow, C. C. (2003). Organizational Strategy, Structure, and Process. California: Stanford University Press. 
Oliver, C. (1991). Strategic Responses to Institutional Processes. The Academy of Management Review, 16(1), 145-179. doi:10.2307/258610.

Otley, D. (2016). The Contingency Theory of Management Accounting and Control: 1980-2014. Management Accounting Research, 31, 45-62. doi:10.1016/j.mar.2016.02.001.

Otley, D. T. (1980). The Contingency Theory of Management Accounting: Achievement and Prognosis. Accounting, Organizations and Society, 5(4), 413-428. doi:10.1016/0361-3682(80)90040-9.

Peteraf, M. A. (1993). The Cornerstones of Competitive Advantage: A Resource-Based View. Strategic Management Journal, 14(3), 179-191. doi:10.1002/smj.4250140303.

Pew Tan, H., Plowman, D., \& Hancock, P. (2007). Intellectual Capital and Financial Returns of Companies. Journal of Intellectual Capital, 8(1), 76-95. doi:10.1108/14691930710715079.

Prajogo, D. I. (2016). The Strategic Fit between Innovation Strategies and Business Environment in Delivering Business Performance. International Journal of Production Economics, 171, 241-249. doi.org/10.1016/j.ijpe.2015.07.037.

Realbusiness.co.uk. (2016). Pressing on with Global Business Growth in an Era of Uncertainty. Real Business. 10 Oktober 2018 (11:30).

Rexhepi, G., Ibraimi, S., \& Veseli, N. (2013). Role of Intellectual Capital in Creating Enterprise Strategy. Procedia - Social and Behavioral Sciences, 75, 44-51. doi:10.1016/j.sbspro.2013.04.006.

Sardo, F., Serrasqueiro, Z., \& Alves, H. (2018). On The Relationship between Intellectual Capital and Financial Performance: A Panel Data Analysis on SME Hotels. International Journal of Hospitality Management, 75, 67-74. doi:10.1016/j.ijhm.2018.03.001.

Senge, P. M. (1990). The Leader's New Work: Building Learning Organizations. 32(1). 10 Oktober $2018(12: 20)$.

Slotegraaf, R. J. (2004). The Paradox of a Marketing Planning Capability. Journal of the Academy of Marketing Science, 32(4), 371-385. doi:10.1177/0092070304265217.

Subramanian, A. \& Nilakanta, S. (1996). Organizational Innovativeness: Exploring The Relationship between Organizational Determinants of Innovation, Types of Innovations, and Measures of Organizational Performance. Omega, 24(6), 631-647. doi:10.1016/S0305-0483(96)00031-X.

Teece, D., \& Leih, S. (2016). Uncertainty, Innovation, and Dynamic Capabilities: An Introduction. California Management Review, 58(4), 5-12. doi:10.1525/cmr.2016.58.4.5.

Tenenhaus, M., Amato, S., \& Vinzi, V. E. (2004). A Global Goodness-of-Fit Index for PLS Structural Equation Modelling. Proceedings of the XLII SIS Scientific Meeting, 1, 739-742.

Tripsas, M. (2008). Customer Preference Discontinuities: A Trigger for Radical Technological Change. Managerial and Decision Economics, 29(2-3), 79-97. doi:10.1002/mde.1389.

Vorhies, D. W., \& Morgan, N. A. (2005). Benchmarking Marketing Capabilities for Sustainable Competitive Advantage. Journal of Marketing, 69(1), 80-94. doi:10.1509/jmkg.69.1.80.55505.

Wernerfelt, B. (1984). A Resource-Based View of The Firm. Strategic Management Journal, 5(2), 171-180. doi:10.1002/smj.4250050207.

Wiklund, J. \& Shepherd, D. (2003). Knowledge-Based Resources, Entrepreneurial Orientation, and The Performance of Small and Medium-Sized Businesses. Strategic Management Journal, 24(13), 1307-1314. doi:10.1002/smj.360.

Wu, G. (2013). The Influence of Green Supply Chain Integration and Environmental Uncertainty on Green Innovation in Taiwan's IT Industry. Supply Chain Management: An International Journal, 18(5), 539-552. doi:10.1108/SCM-06-2012-0201.

Yalabik, B., \& Fairchild, R. J. (2011). Customer, Regulatory, and Competitive Pressure as Drivers of Environmental Innovation. International Journal of Production Economics, 131(2), 519-527. doi:10.1016/j.jpe.2011.01.020.

Zahra, S. A., \& Covin, J. G. (1993). Business Strategy, Technology Policy and Firm Performance. Strategic Management Journal, 14(6), 451-478. doi:10.1002/smj.4250140605. 
Halaman ini sengaja dibiarkan kosong 